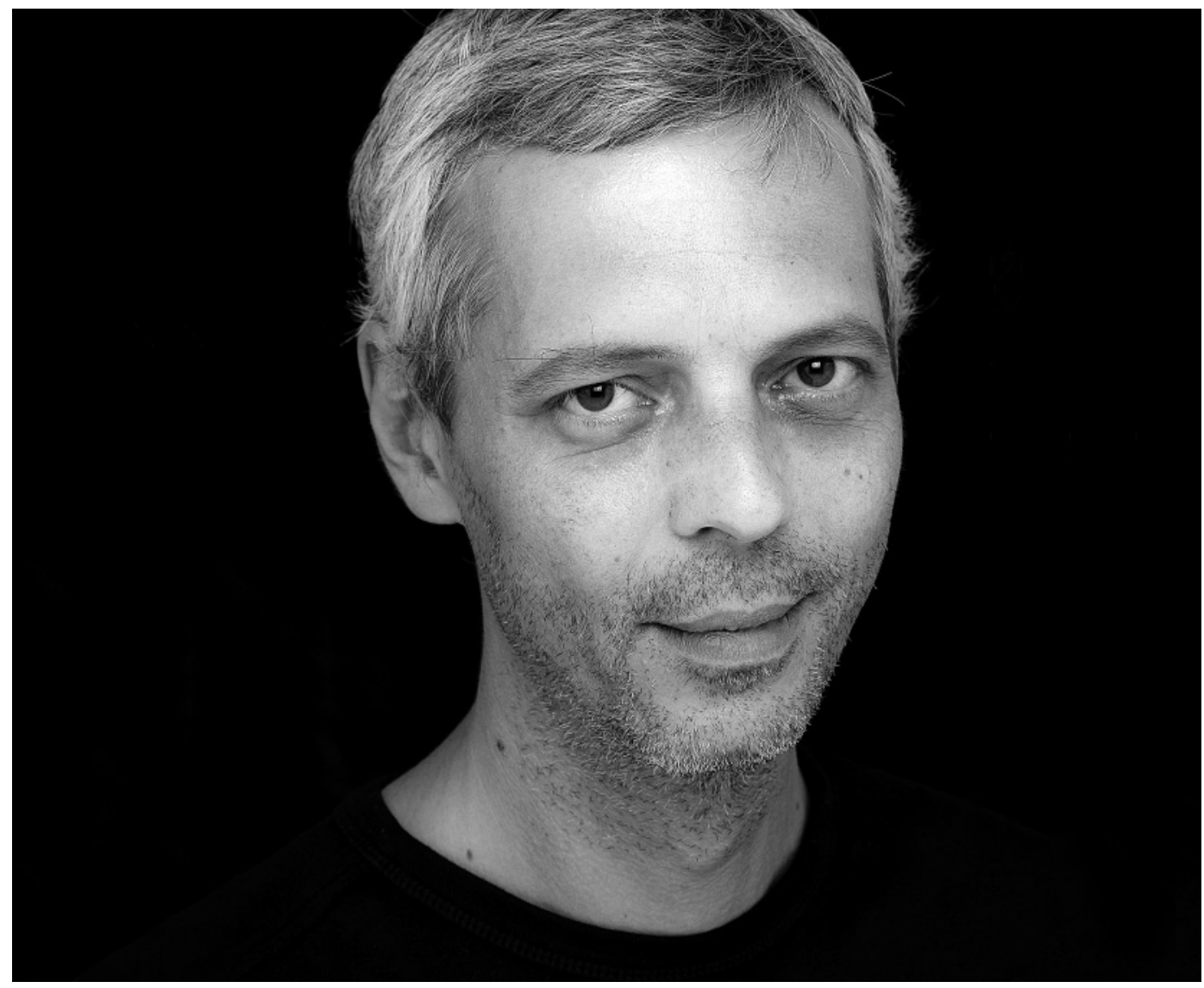

\title{
José Luís Ferreira: 0 território da intervenção
}

\section{João Carneiro e Alexandra Moreira da Silva}

Do teatro Gil Vicente, passando pelo Teatro Nacional São João, até à actual direcção do São Luiz Teatro Municipal, o percurso profissional de José Luís Ferreira é, segundo o próprio, tão circunstancial quanto o título do ensaio ("Não é fácil") que escreveu e publicou em 2009 , em conjunto com Fernando Mora Ramos, Américo Rodrigues e Manuel Portela. Talvez "os acasos" tenham ajudado, mas o que mais se destaca nesse mesmo ensaio é a determinação, a clareza de pontos de vista, e a persistência informada que estarão na origem não só da sua reflexão sobre política cultural e de programação, como também da sua ampla actividade no âmbito do teatro. Programador, director de produção e de projectos internacionais, assumido defensor de projectos em rede, José Luis Ferreira coordena, até 2010, o Departamento de Relações Internacionais do TNSJ, e inscreve no seu percurso várias experiências de dimensão nacional e internacional, das quais destacaríamos o Festival PoNTI, a programação da Capital Europeia da Cultura - Porto 2001, o Festival da União de Teatros da Europa, o Portogofone (showcase de teatro português e encontro internacional de criadores e profissionais de teatro), o fórum Teatro Europa, e mais recentemente o projecto de "investigação, formação, criação e mediação" Odisseia. Em Dezembro de 2010 é classificado em primeiro lugar no Concurso para o cargo de Direcção Artística do SLTM. Foi, precisamente no SLTM que José Luis Ferreira nos recebeu e respondeu às nossas questões com a determinação, a clareza e a persistência informada que o caracterizam - ainda que, como deixa escapar, na base de tudo isto possa estar "uma ideia relativamente romântica sobre a criação".

Alexandra Moreira da Silva: No livro Quatro ensaios à boca de cena o título do teu texto é "Não é fácil". De acordo com a tua biografia não foi fácil chegar aqui. Passas por várias etapas no teu percurso, que são também etapas geográficas, de Coimbra para o Porto, do Porto para Lisboa. Comecemos pelo princípio: como é que chegas ao teatro?

José Luís Ferreira: Já que começaste pelo título do ensaio, pode fazer-se outro paralelo: o meu percurso é tão circunstancial como o título desse ensaio. 0 texto começa com as palavras "não é fácil falar de cultura em Portugal" e o word assumiu "não é fácil" como título do documento. 0 meu percurso, também, não sei se alguma vez procurei construí-lo de maneira muito sustentada. Acho que ele tem muito a ver com os acasos de tudo o que se faz em Portugal. Tem a ver com uma professora de filosofia que tive no liceu e que achava que a expressão dramática era um meio excelente para tratar de certos temas que ela tinha de tratar nas aulas. Dai à constituição de um grupo 

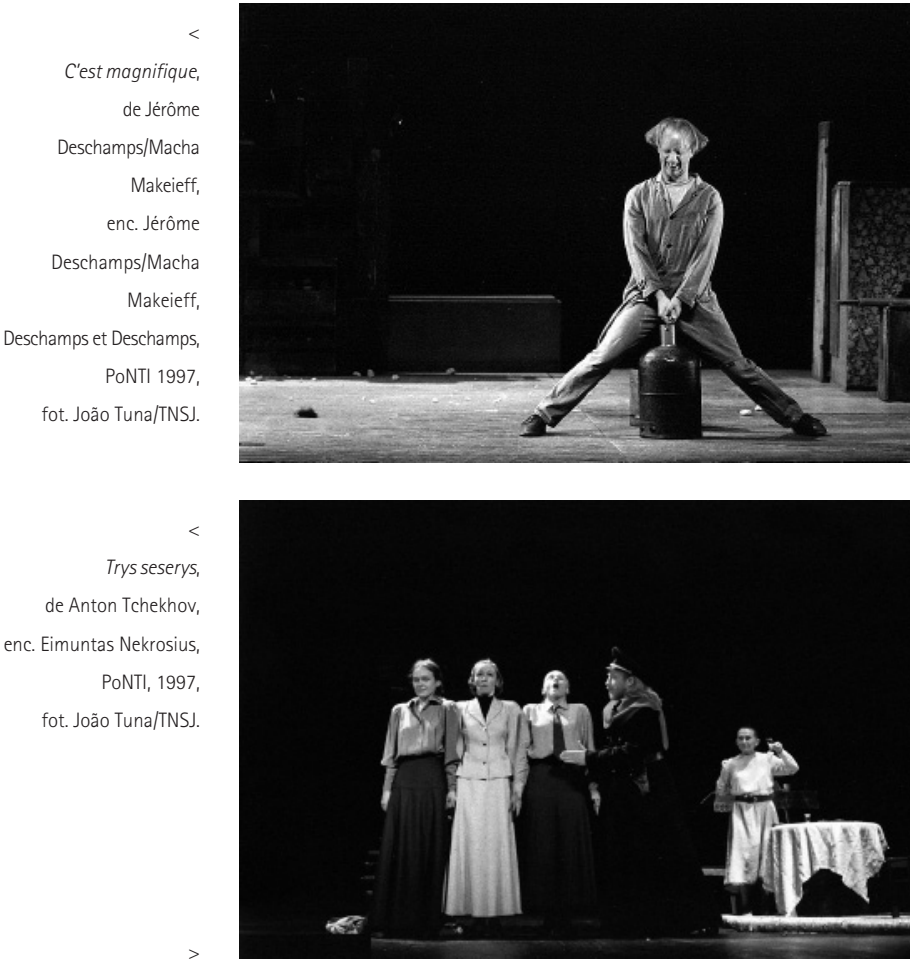

Amleto

de Romeo Castellucei

a partir de Shakespeare e

Grammaticus,

enc. Romeo Castellucci

Societas Raffaello Sanzio,

PoNTI 1997

fot Societas Raffaello

Sanzio.

Ricardo Pais foi director do TNDMII entre 1989 e

1999, 2001 e 2004

${ }^{3} 0$ FIT - Festival

teve quatro edições anuais de 1991 a 1994. de teatro no liceu foi um pequeno passo. Isto passou-se em Leiria. Deu-se a coincidência de o Teatro Experimenta de Leiria ter o seu espaço mesmo em frente ao liceu, de eu conhecer o filho de umas das actrizes, e de conhecer o encenador que era o Carlos Fragateiro. Depois o TEUC foi mais ou menos inevitável. Foi sempre um percurso um bocadinho marginal, foram sempre acontecendo coisas que fizeram com que o meu percurso não fosse muito central, como eu achar que na altura o TEUC estava num período um bocadinho conturbado. Nunca fui mesmo sócio do TEUC. Fiz só um curso de iniciação ao teatro. Depois tive a sorte de apanhar Coimbra num dos momentos mais efervescentes que aquela cidade teve nas últimas décadas, no final dos anos oitenta e início dos anos noventa, o que acabou por dar origem a duas companhias de teatro: a Escola da Noite, que ficou em Coimbra, e a Visões Úteis que acabou por migrar para o Porto. Também por coincidência a Universidade de Coimbra decidiu abrir um concurso para a direcção artística do Teatro Gil Vicente e o António Augusto Barros ganhou esse concurso. Eu tinha acabado de trabalhar com ele na bienal de Coimbra, em 1991 e ele tinha sido nomeado director artístico do teatro Gil Vicente. Como ele geralmente pensa os seus projectos em várias frentes, inclusive como distribuir os seus recursos no território, para garantir a sua realização, achou que eu poderia ser um recurso importante para não afectar os restantes projectos que tinha entre mãos. É evidente que sempre tive muito prazer com o teatro: as pessoas que eu conhecia pertenciam a este universo. Tive uma filha muito cedo e precisei de começar a trabalhar, e o primeiro trabalho que arranjei foi nesta área.

AMS: Continuaste, de facto, nesta área, e em 1997 vais para o Teatro Nacional São João.

JLF: Ao longo desses anos foram acontecendo algumas coisas em por lá, como Coimbra - Capital do Teatro, em

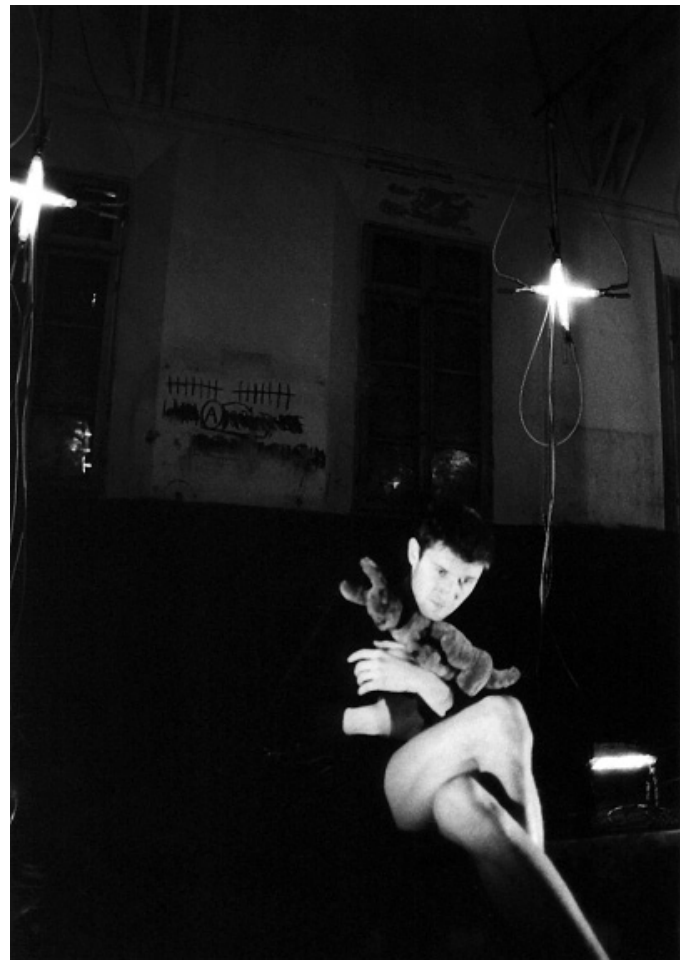

1992-93. E conheci o Ricardo Pais, que foi comissário dessa iniciativa. Isso permitiu a transição, um ano e tal depois de o Ricardo ter sido nomeado director do São João, para o Porto. De início as minhas funções eram relativamente indeterminadas: tratava-se de uma assistência de direcção, portanto, secundá-lo e ajudá-lo em várias coisas, coisas básicas. Foi exaltante porque 0 teatro estava em construção. Era a invenção de uma possibilidade de negar a herança mais ou menos errática do Teatro Nacional D. Maria II', e comprovar que era possivel construir uma outra matriz de teatro nacional. Um pouco por acaso, também, logo de início deu-se uma dimensão internacional ao projecto do S. João, através da realização do PoNTI' ${ }^{2}$ que nasceu de um desejo conjunto do Ministério da Cultura e do S. João, retomando uma tradição, uma prática, interrompida com o fim do $\mathrm{FIT}^{3}$, em Lisboa; o PoNTI deveria ser um festival que pusesse 0 Teatro S. João nas rotas internacionais de circulação do teatro. Na altura o projecto foi feito sob pressão, entrei no teatro em 1997, o festival foi decidido em Maio e realizou-se em Dezembro. Reuniu-se na altura aquilo que já era a capacidade de realização do teatro e a colaboração de alguns amigos com alguma experiência internacional evidente e reconhecida. Isso para além da aventura fantástica que foi criar o festival, pôr uma cidade como o Porto em contacto frenético e imediato com áreas da criação que eram bastante desconhecidas do público. Fo o primeiro passo para se começarem a construir relações internacionais constantes: quer com criadores, quer com companhias, produtores ou festivais. Isso foi-se constituindo, por tentativa e erro, como uma área de trabalho mais concreta dentro do São João, que eu fui ajudando a construir.

João Carneiro: Desde então ficaste também ligado a uma articulação entre a componente artística e administrativa? Como foi isso? 


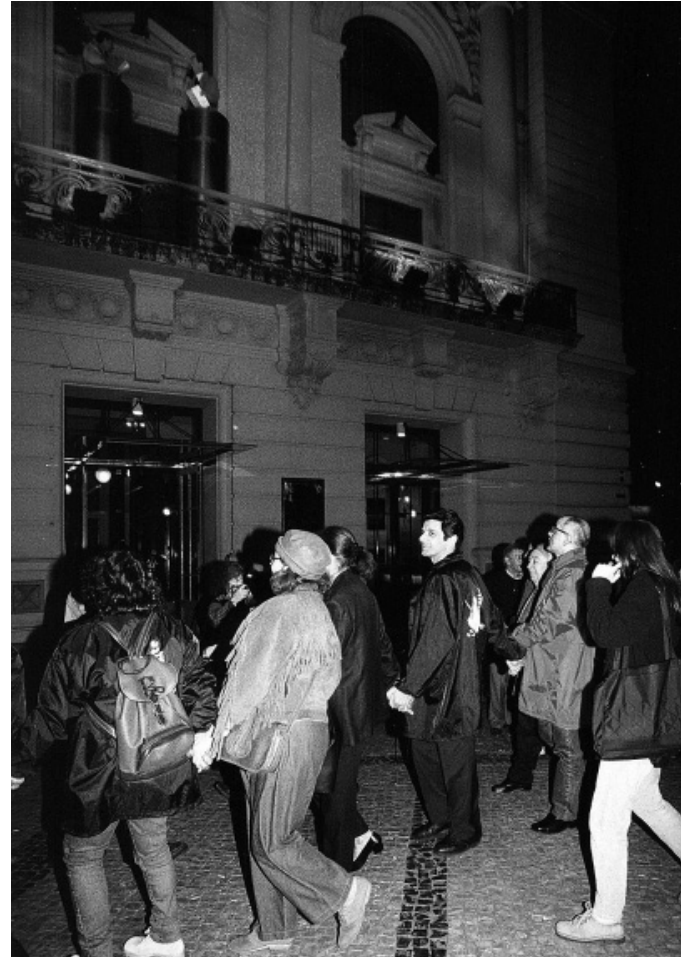

JLF: A minha inscrição nos projectos foi sempre bastante intuitiva, por isso eu agora enfrento desafios bastante duros. Tivemos a percepção, na altura, que aquele festival, para além do que significava como festival, tinha um significado também na via do trabalho, e que essa via tinha de se estruturar dentro do teatro. Apesar de eu ter outras atribuições, essencialmente na área da comunicação, a área das relações internacionais tornou-se mesmo uma realidade. Isso gerou sempre um movimento que implicou um raciocínio de produção num sentido mais administrativo, mas simultaneamente a tentativa de exploração de relações reais ao nivel artístico, implicando não apenas a recepção de projectos vindos de fora, como também a circulação de projectos do São João, ou a realização de projectos conjuntos, de criação ou de produção, em que essas duas dimensões nunca estiveram desligadas. Se eu comecei por dizer que essa minha aproximação intuitiva me traz problemas hoje, porque me obriga a estruturar um raciocínio de gestão ao assumir a direcção artística de um teatro como o São Luiz, isso também não me é totalmente estranho, porque venho de uma escola em que esses dois aspectos não estão separados, quer dizer, o modo como se cria uma obra e o modo como se gere a possibilidade de a fazer.

AMS: Quando pensamos no JLF associado a uma estrutura como o Teatro Nacional São João pensamos em três coisas, essencialmente: internacionalização, festivais e projectos em rede. Sempre foste um grande defensor desta última ideia: é algo que surgiu, que abraçaste e que tentaste implementar. 0 que é que isto significa em termos de dinâmica para um Teatro Nacional?

JLF: É dificil dizer se ela nasceu de mim, isto sem falsa modéstia. Durante esse periodo, em que estávamos muito concentrados na construção de um projecto de teatro, era muito difícil dizer de onde vinham as ideias. Elas
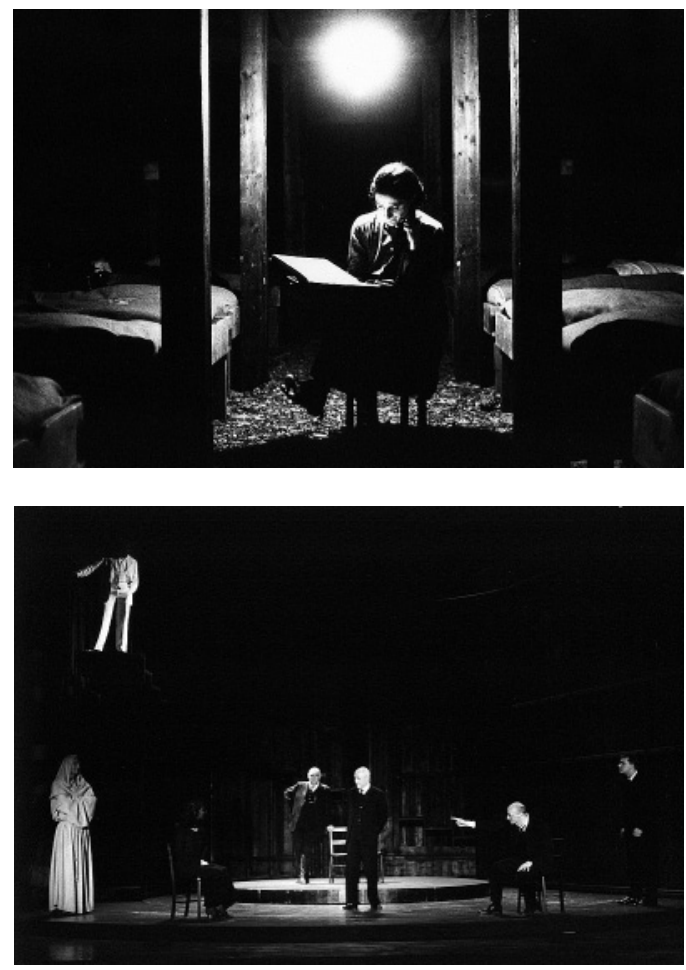

vinham e eram sedimentadas pela consciência geral do projecto e pela energia do Ricardo [Pais], e depois por contributos singulares de todos nós. A ideia que o Ricardo tinha para um Teatro Nacional era uma ideia muito centrada num centro de criação. Não era nem muito viável nem muito desejável ter uma companhia permanente, embora ele tivesse procurado ter um elemento constante, e transformar aquilo que era a programação numa prática de repertório e quase uma prática formativa. E isso implica métodos que são muito orientados para dentro, para a sala de ensaios, para a construção de projectos, etc. Era necessário ter alguém dentro do teatro que pudesse articular esse aspecto com o lado de fora. Dado este conjunto de coincidências e porque a direcção artística achava que isto era um aspecto Ihe competia acompanhar, mas que não tinha tempo para o fazer sozinha, eu fui desenvolvendo trabalho aí. Nunca tive formação em nenhuma destas áreas, nunca tive experiências de transmissão muito estruturadas, de maneira que foi uma realidade que foi sempre sendo conquistada, construida....

AMS: E destes projectos em rede, que projecto citarias como grande exemplo do que acabas de dizer?

JLF: É um pouco estranho começar pelo fim, mas o Projecto Odisseia (2011) é o grande exemplo. Nunca tinha havido possibilidade de fazer um projecto em rede no plano nacional e no plano internacional, confluindo para uma mesma realidade. Isso permitiu também incrementar bastante o orçamento do teatro neste tempo de crise, através da compreensão do que pode ser a complementaridade entre aquilo que são os fundos habituais do teatro e aquilo que são os fundos de desenvolvimento regional, no momento em que o norte quer afirmar-se como lugar de excelência no plano internacional no âmbito das indústrias criativas, com tudo o que esse facto significa para as instituições culturais do Porto, nomeadamente perceberem como é que o seu
Abraço ao teatro, noite de 26 de Março de 1997, fot. Lucilia Monteiro.

Buchettino,

a partir de Charles Perrault, enc. Chiara Guidi, Societas Raffaello Sanzio, PoNTI 1997, fot. João Tuna/TNSJ.

Measure for Measure de William Shakespeare enc. Stéphane Braunschweig, Edinburgh International Festival/Nottingham Playhouse/Barbican Centre, PoNTI 1997, fot. João Tuna/TNSJ. 


\section{Voices, \\ a partir de textos de \\ Pier Paolo Pasolini \\ e Cor Herkströter, \\ enc. Johan Simons, \\ Theatergroep Hollandia, \\ PoNTI 1999, \\ fot. João Tuna/TNSJ.}

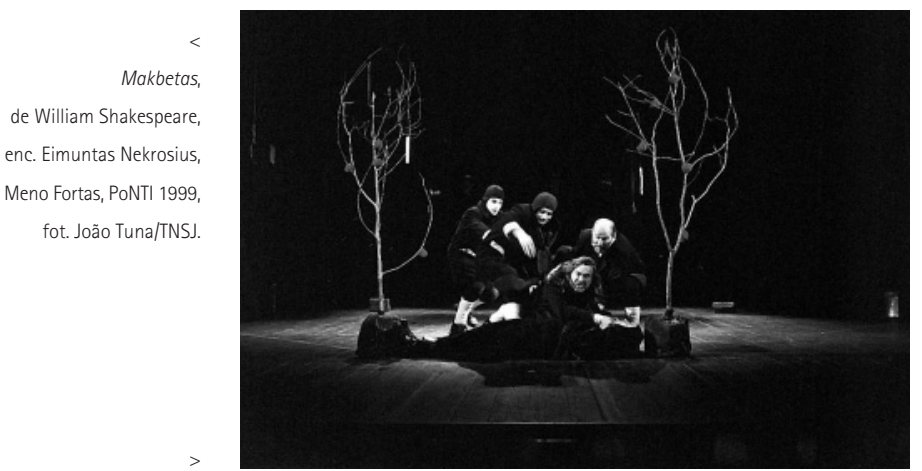

Some Explicit Polaroids,

de Mark Ravenhill,

enc. Max Stafford-Clark,

Out of Joint, PoNTI 1999,

fot. João Tuna/TNSJ.

The Days Before,

de Robert Wilson,

a partir de Allha do Dia Antes de Umberto Eco,

enc. Robert Wilson,

Change Performing Arts,

PoNTI 1999,

fot. João Tuna/TNSJ. trabalhar em conjunto com três teatros municipais, ensaiar trabalho se pode inscrever no futuro mais ou menos radioso que se anuncia. Portanto, isto foi bonito, porque permitiu num mesmo projecto tentar perceber como é que se trabalha em conjunto, como é que o São João pode o que podem ser mecanismos de cooperação numa perspectiva da tal rede nacional de teatros, perceber como é que, em conjunto, companhias internacionais, artistas, formadores se podem inscrever naquele espaço sem ser só no Porto, mas num espaço regional, o que é que isso pode trazer a cada um deles, e ao mesmo tempo aproveitar a inscrição numa rede europeia, a UTE [Union des Théâtres de l'Europe], que, para além do valor institucional que tenha, permite contacto directo e permanente com vinte ou trinta pessoas do espaço europeu. Isso faz com que, quando começas a esboçar uma ideia, haja rapidamente contributos que tornam essa ideia mais densa e interessante para toda a gente, mesmo que depois isso não se venha a concretizar com um determinado parceiro.

AMS: Em que é que consiste este projecto?

JLF: 0 projecto Odisseia tem um subtitulo relativamente pomposo, que é "investigação, formação, criação, mediação". E tendo nós procurado fazer um projecto internacional modelar, enquanto projecto em rede, enquanto raciocínio que alie dimensões de formação e criação, para qualificar as práticas de criadores,

principalmente no plano local, como é que se pode usar isso para comunicar com os públicos e mostrar e perceber que o exercício teatral não é um exercício desligado da realidade, mas um exercício que reflecte sobre a realidade e procura caminhos de compreensão da realidade. Assim, o projecto é também concebido como um percurso que vai da ideia inicial de investigação até à ideia final de mediação das criações com os públicos. E como projecto também académico começou com um colóquio em que se discutiu não só a temática específica do projecto, ou
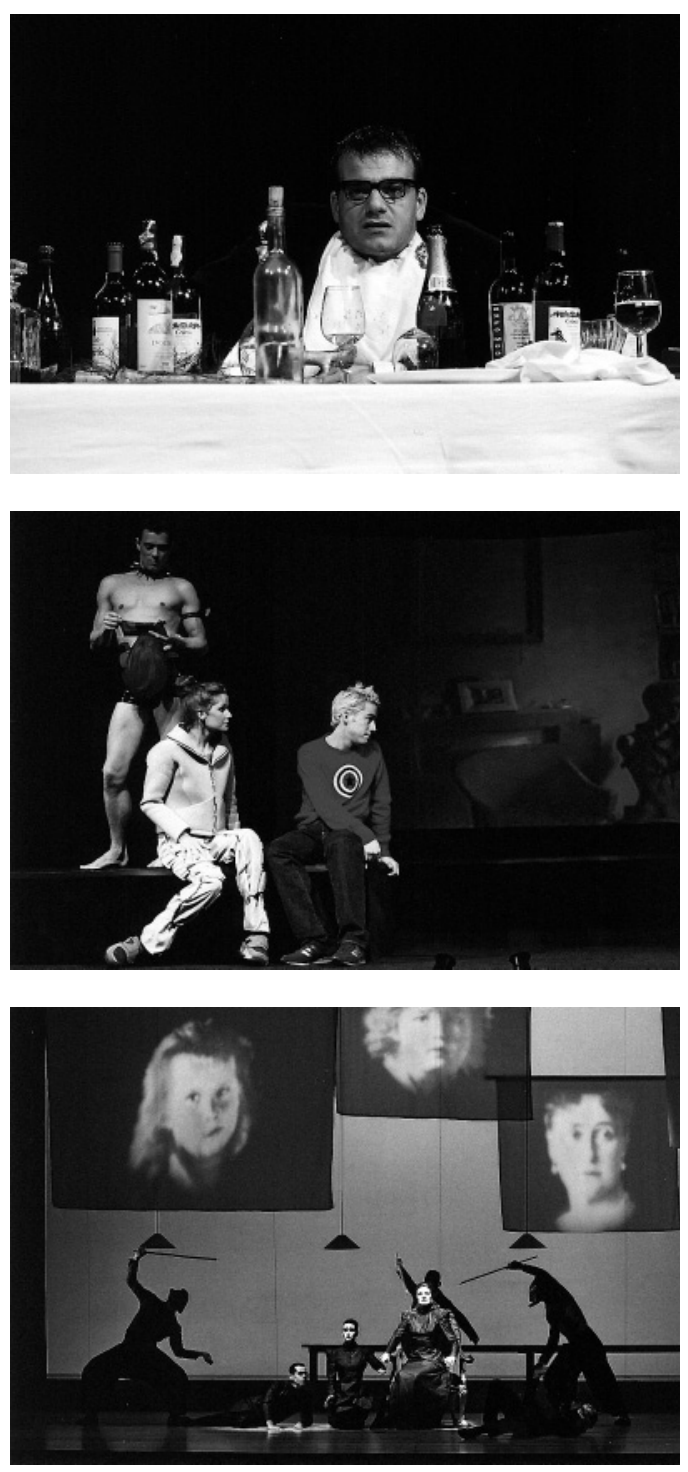

seja, a Odisseia de Homero e a ideia do homem em viagem à procura de si próprio, em confronto com a sua identidade e em confronto com a alteridade, de um ponto de vista aliás bastante truculento e não necessariamente correcto politicamente, que é o da figura de Ulisses. Não estamos com um herói modelar no sentido de compreensão do outro: vai-se enriquecendo, mas é sempre um homem centrado em si e, quando regressa a İtaca, é o homem europeu moderno, se se pode dizer, o que também vai fazer os descobrimentos, conquistar o oeste, colonizar, ocupar, etc., ou seja, há também um lado irónico e autoreflexivo na escolha deste tema. Foi assim, pensar a Odisseia enquanto um texto matricial da nossa cultura e na maneira como na Europa contemporânea os projectos internacionais na área do teatro podem contribuir para que a Europa seja algo mais do que um território da economia e das finanças, e seja uma realidade cultural que tem vinte e três línguas oficiais, três alfabetos, dezenas de dialectos, uma grande diversidade cultural, e em que também se podem empreender projectos em conjunto. Podemos perguntar o que é que essa dimensão internacional traz de concreto a cada um desses projectos de criação. Começámos por investigar o que é a Odisseia numa possivel relação com a natureza de projectos internacionais na 


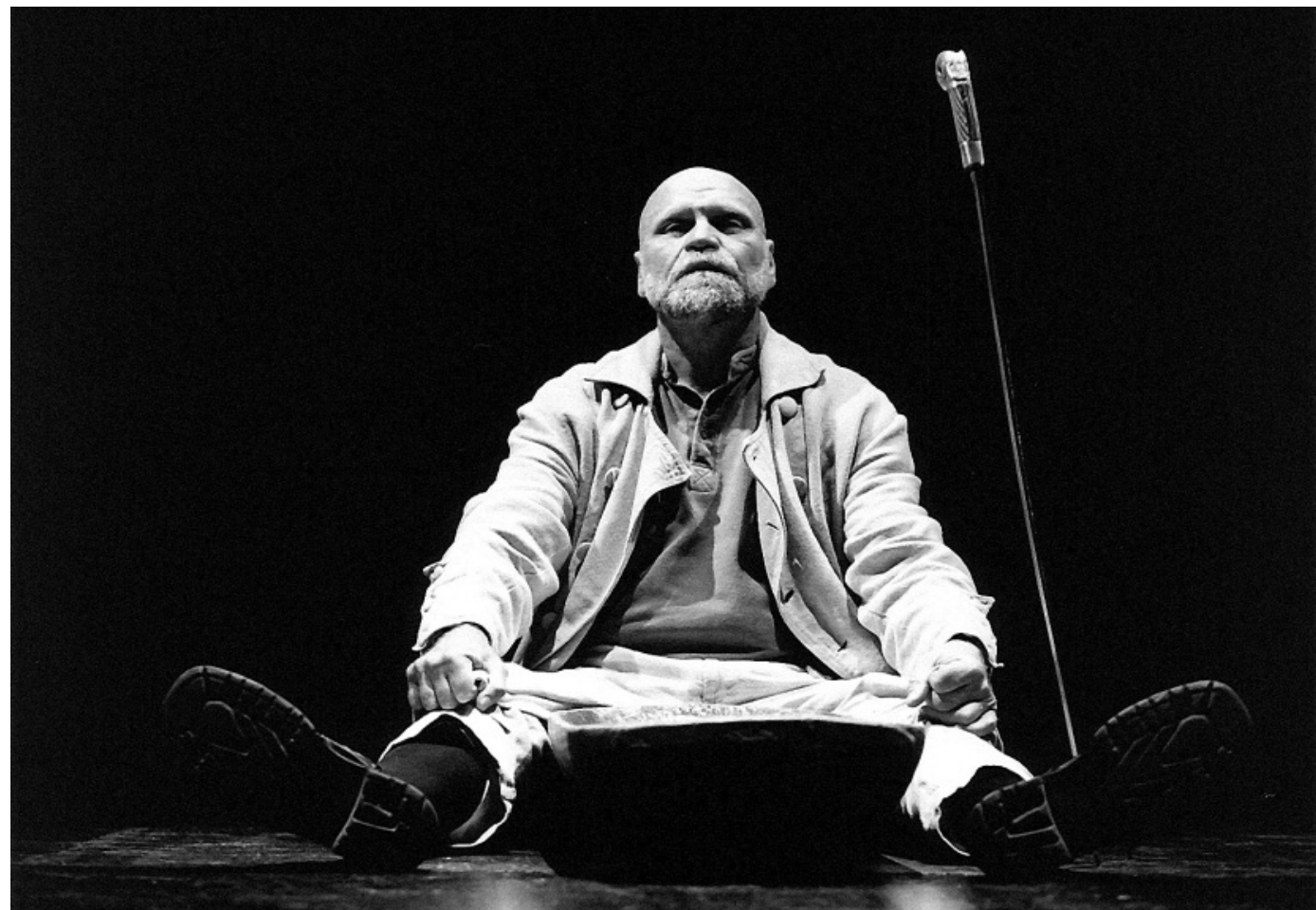

Otelas,

de William Shakespeare enc. Eimuntas Nekrosius, prod. Aldo Grompone, PoNTI 2001, fot. João Tuna/TNSJ.

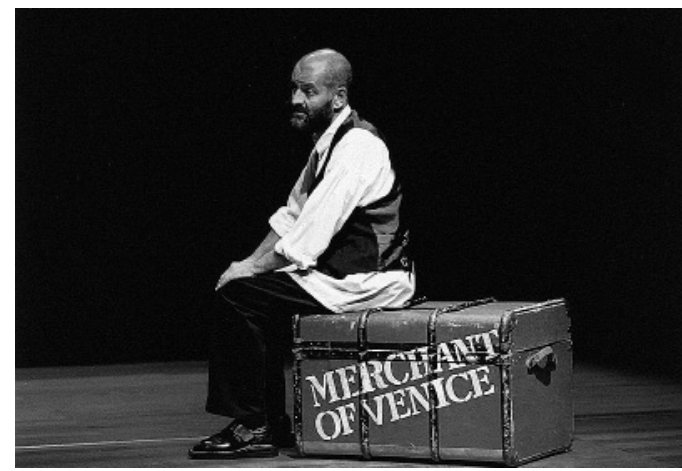

área do teatro. Depois passámos para uma segunda fase, essencialmente de formação, ou seja: para corresponder aos objectivos do cluster das indústrias criativas, fazer aquilo a que chamamos criação em laboratório, ou seja, processos que vão da formação pura até à experiência que, sendo de transmissão e de formação, acabam por provocar fenómenos de criação. Isso implica que a aprendizagem se transforme em novas coisas, como foi o projecto do Jean-Pierre Sarrazac. E este processo de criação em laboratório, que procura transformar o processo normal de criação, fez confluir estudantes, naquele caso um conjunto de alunos da ESMAE (Escola Superior de Música e Artes do Espectáculo) que seguiu todo o processo, num estágio intenso de cerca de dois meses. Uma outra experiência, o da companhia teatral europeia, um projecto de futuro, de momento em esboço, que está ainda de tal modo sem forma que pode vir a ser tudo, e que permitiu incluir actores portugueses numa produção plurinacional dirigida por um encenador escocês, num processo que se passa essencialmente no Porto mas que depois irradia para outros espaços, do pais e de fora. Depois chegamos à dimensão da mediação, e aí não nos interessava fazer um modelo de festival clássico essencialmente centrado no acolhimento e na difusão: já tinhamos feito o PoNTI,

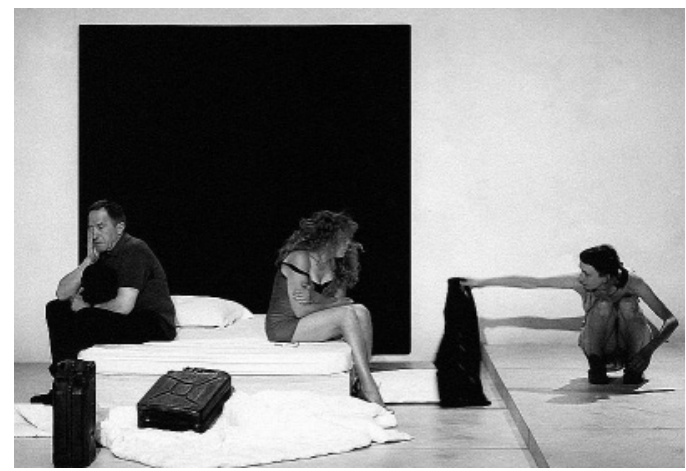

em quatro edições, uma aventura fantástica. Agora, interessava-nos mais um modelo em que a presença de criadores e companhias no Porto permitisse deixar - junto de companhias, de espectadores, da comunidade e dos poderes públicos - a ideia de que, quando estamos a falar de investimento público na criação artística, principalmente no domínio do teatro, estamos a falar de algo mais do que estar a subsidiar, com actos de príncipe, coisas que são mais ou menos bem sucedidas do ponto de vista estético. Queremos provar que estamos a investir num tecido, numa rede de povos/pontos suficientemente fortes, suficientemente autónomos, que possa fazer crescer o nosso universo simbólico, que possa fazer perceber a relação entre estas coisas e o exercício da cidadania.

AMS: Isso significa que os participantes neste festival, para além de apresentarem espectáculos, participam também nessas dimensões de criação, de formação e de mediação do projecto.

JLF: Em geral todas as companhias têm um momento de contacto quer com os jovens estudantes de áreas artísticas, quer com jovens profissionais dessas áreas, porque uma da muitas preocupações que confluíram neste projecto foi a consciência de que a profissionalização é muito difícil,
Shylock,

de Gareth Armstrong, enc. Frank Barrie, prod. Gareth Armstrong, PoNTI 2001, fot. João Tuna/TNSJ.

Visage de feu, de Marius von Mayenburg, enc. Alain Françon, Théâtre National de la Colline, PoNTI 2001, fot. João Tuna/TNSJ. 


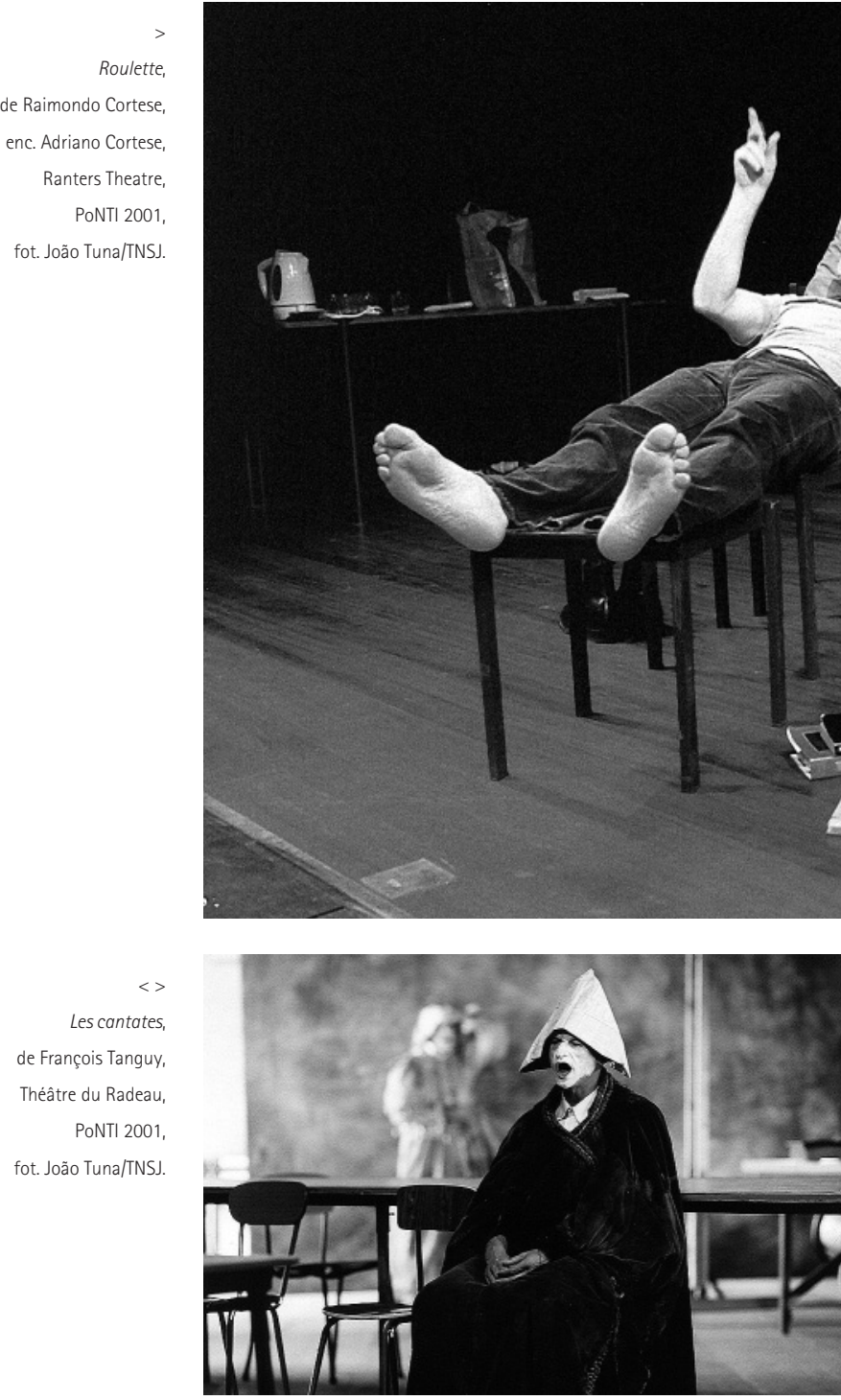

e a passagem da profissionalização para uma vida profissional real não é nada fácil e faz-se muitas vezes de descontinuidades e inconsistências. Há excepções, talentos que têm logo um raciocínio que transporta uma ideia de produção, mas em geral o que espera os jovens artistas, depois da formação, são projectos frágeis, descontínuos, que não permitem crescimento, nem sequer acumulação de experiência. Portanto, uma das principais ideias de pôr estas companhias internacionais a trabalhar no terreno é a de partilhar métodos, fazer com que esses jovens artistas tenham uma experiência acelerada que Ihes permita abrir horizontes, despertar a curiosidade, aumentar a possibilidade de prosseguirem a sua formação, partilhar métodos, mostrar que não há só uma via de prosseguirem as suas vidas.

JC: Antes de um momento inicial, entre o primeiro PoNTI e a Odisseia, entre um primeiro festival, que é uma apresentação de espectáculos relativamente informal, e a Odisseia, que tem estratégias muito próprias e definidas, o que é que se passa na tua maneira de olhar para a criação artística?

JLF: Tenho uma ideia relativamente romântica sobre a criação: continuo a achar que, no limite, o que é importante

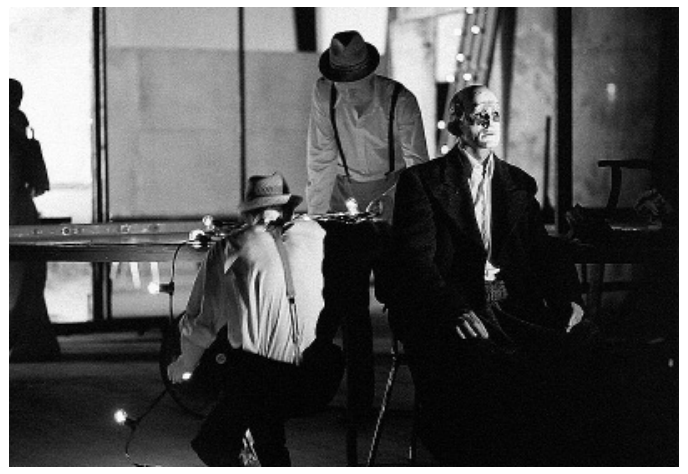

é conseguir meios e criar oportunidades para deixar as pessoas prosseguirem tranquilamente os seus processos artísticos, e investirem na partilha desses processos de criação artística, dado que o teatro é uma arte colectiva. Mas fui amadurecendo uma ideia que não será original: a de que os objectos, que resultam desses processos de criação artística, só são importantes se conseguirem acrescentar algo à experiência do mundo e se conseguirem estabelecer um diálogo real com pessoas reais, e que isso é mais interessante se se passar ao nivel intelectual, de raciocinio sobre o real, por detrás do qual está o social e o político. Ou seja, quando estamos a fazer arte - e com isso a alterar a cultura - estamos também a alterar a nossa visão do mundo e a alterar o mundo, a intervir nele, a alterar e aprofundar os nossos modos de intervenção.

JC: Uma actividade como a tua envolve reflexões estratégicas e noções sobre aquilo que é ou deve ser o teatro. Uma delas, por exemplo, é a noção de abertura de horizontes, a noção de inclusão, artística e social, num universo complicadamente em expansão. Até que ponto esse discurso sobre abertura e inclusão não implica uma conformação, uma configuração da criação artística? 


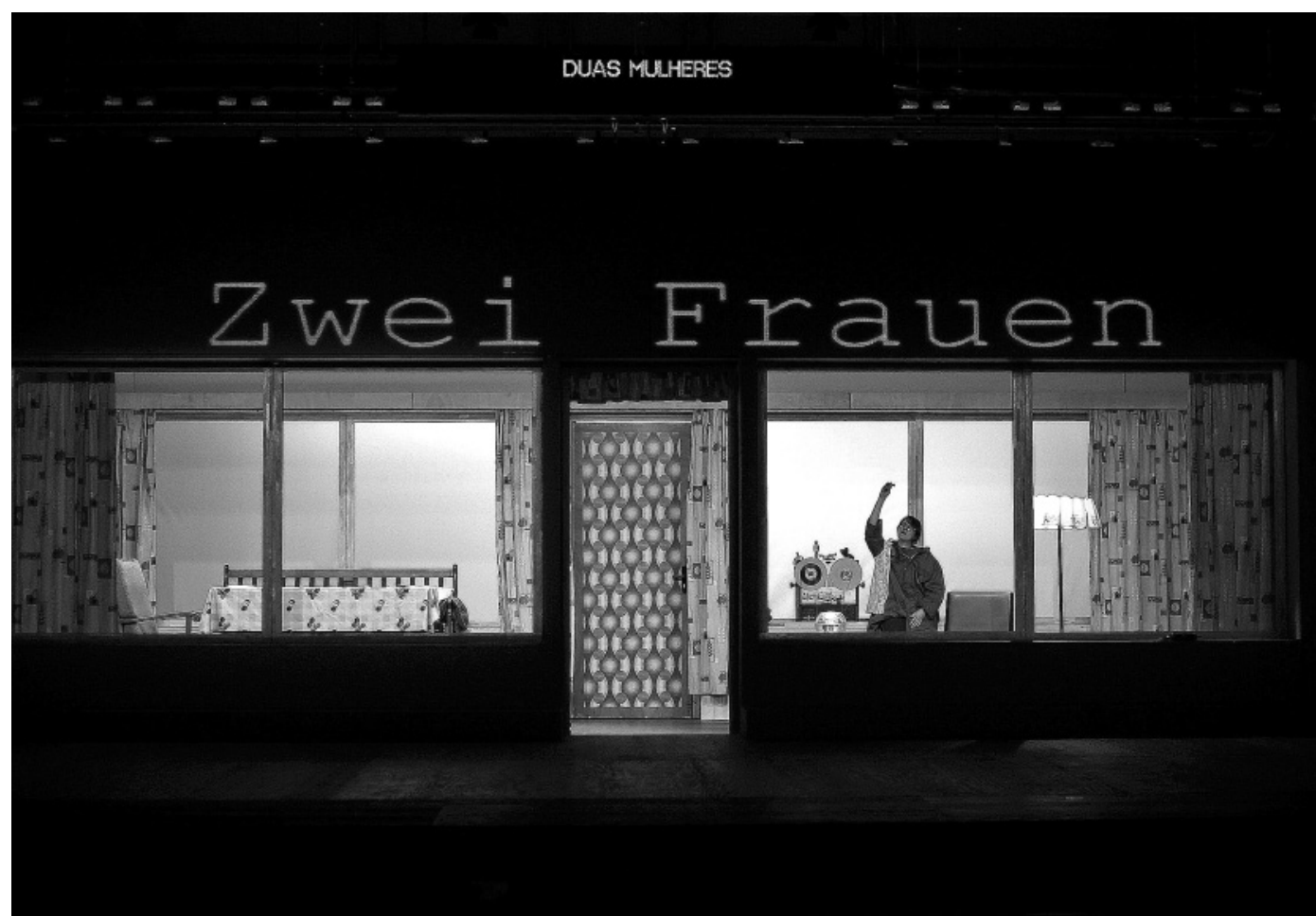

JLF: Ainda bem que me perguntas isso, porque há um risco muito grande de confusão entre as duas coisas. Os termos da tua questão lembram-me os termos em que a Comissão Europeia lançou há uns quatro ou cinco anos o projecto da agenda cultural para a Europa, que era um esboço das grandes traves de uma política cultural europeia, e nesse sentido os objectivos de então eram os da coesão social, o diálogo intercultural, a promoção externa da imagem da Comissão Europeia, entre outros. E sim, claro que acho que esse caminho é uma perversão da ideia ou raciocínio que eu expus antes.

\section{JC: Ou não....}

JLF: Trata-se de uma forma muito clara de evitar aquilo que não se compreende, que é a realidade específica dos fenómenos de criação artística, e a vontade e o desejo político de os estados os integrarem enquanto política pública, de apoiar instituições públicas que se dedicam a essa área, ou seja, ao não se conseguir compreender o que é a realidade específica e concreta da criação, instrumentaliza-se o que é o apoio, o financiamento público da criação. Porque as pessoas tocam um instrumento, ou pintam, isso pode resultar num mundo melhor, mas isso é sempre um resultado de fim de linha, não sindicável. Há uma instrumentalização no uso que se faz deste discurso das indústrias criativas e culturais, que deixa de lado o centro que é a criação artística. E contra isso já me fui manifestando, quer por escrito, quer pela maneira como vou organizando os projectos. É que do outro lado da questão existem duas realidades: por um lado, a dos criadores que têm uma responsabilidade social e, na minha avaliação do que são os projectos reais, estes são tanto mais consistentes quanto mais incorporam o que é e a experiência do mundo no seu trabalho; por outro lado, no que respeita a instituições como o São Luiz, por exemplo, há uma responsabilidade acrescida, e agora ainda mais com a crescente asfixia de recursos, e dado que cada decisão tem de ser pesada de acordo com os efeitos que produz no tecido de produção e de criação, uma necessidade acrescida de que cada gesto de programação, cada investimento em cada projecto, procure não só densificar e aumentar a experiência de cada projecto artístico, mas estabelecer um diálogo real com uma cidade real, com um país real. É um jogo relativamente complexo entre as tentações mais ou menos economicistas, ou de desenho das intervenções no mundo das artes, que tem de se jogar com uma consciência que vem do lado da criação. Há uma citação do Bernard Stiegler no meu artigo, mal transcrita até, segundo a qual recusar jogar esse jogo corre o risco de transformar a cultura e as artes numa espécie de reserva de índios, um espaço desvitalizado.

AMS: Passamos a Lisboa. Concorreste a este lugar. Disseste que foi importante o processo do concurso público pelo qual foste escolhido. Em quê que se traduz essa importância?

JLF: Acho que isso tem importância pessoal e política. Por um lado aponta um método, um processo, um processo relativamente neutro e essencialmente bem construído. Começa com a encomenda, elaboração e publicação de uma estratégia cultural para a cidade, que é um documento aceitável e legível por todos, elaborado pela Câmara Municipal de Lisboa, que passa por usar essa estratégia para apontar caminhos concretos para aquilo que é investimento da CML na área da cultura. Depois há um passo a seguir, e esses princípios são para ser aplicados; e diz-se ainda que os directores artísticos dos equipamentos municipais devem ser escolhidos por concurso público. Foi aberto um concurso público e isso permite, para além da justeza democrática do processo - até por estar mais sujeito a uma sindicância pública - que aconteça o improvável: vir eu a assumir um projecto deste tipo, no teatro municipal porventura mais exposto de Lisboa e do país. E improvável porque eu nunca tinha vivido nem 


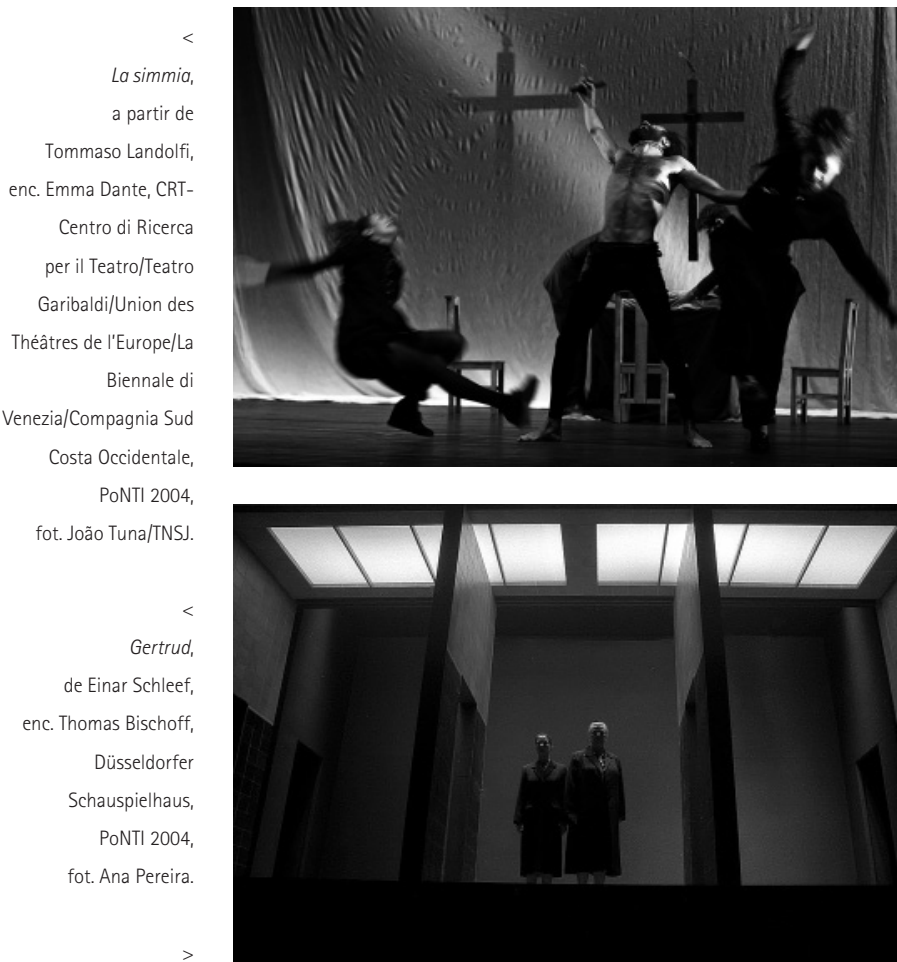

A lliada: Canto XXIII, a partir de Homero, enc. Anatoli Vassiliev, Teatro de Moscovo Escola de Arte Dramática,

PoNTI 2004, fot. João Tuna/TNS trabalhado em Lisboa, nunca tinha dado provas nesta cidade, apesar de um percurso profissional com já alguns anos.

JC: E o teu projecto para este teatro implica grandes alterações relativamente ao que tem sido o São Luiz? JLF: Não, ruptura não, acho que este teatro, desde que passou a ter uma direcção artística continuada e com objectivos claros, foi afirmando uma imagem de relação com a cidade e de transparência com o trabalho das comunidades artísticas de Lisboa e do país com a qual não faria sentido nenhum romper. E apesar de poder utilizar palavras diferentes para chegar a objectivos idênticos ou semelhantes, eu penso que o Jorge Salavisa concordará comigo: penso que um teatro municipal, e sobretudo este teatro municipal, dado o lugar que tem na estratégia cultural da CML, é necessariamente um espaço popular, um espaço eclético, que procura construir uma identidade não a partir de linhas programáticas que o façam diferente, mas por corresponder ao mesmo tempo a necessidades do público e a necessidades do tecido artístico. Portanto, às necessidades da cidade. E isso implica a pluridisciplinaridade, a busca de projectos que queiram comunicar com públicos mais alargados, porque nem todos os projectos de criação o querem, e nem todos os projectos são válidos por corresponderem a este desenho. Mas finalmente neste momento na cidade de Lisboa há uma rede de espaços que permite uma diferenciação de programação a esse nível. Este é, de alguma maneira, ou gostaria de ser, um teatro nacional popular, um pouco à imagem da ideia do teatro nacional popular francês.

JC: Que ideia de cidade é que uma pessoa tem ou precisa de ter para assumir a direcção deste teatro? JLF: Quanto mais profunda e ancorada for essa ideia, ou percepção da cidade, melhor. Isso pode ser um handicap, para mim, ou talvez não. Não conhecia a cidade, mas o

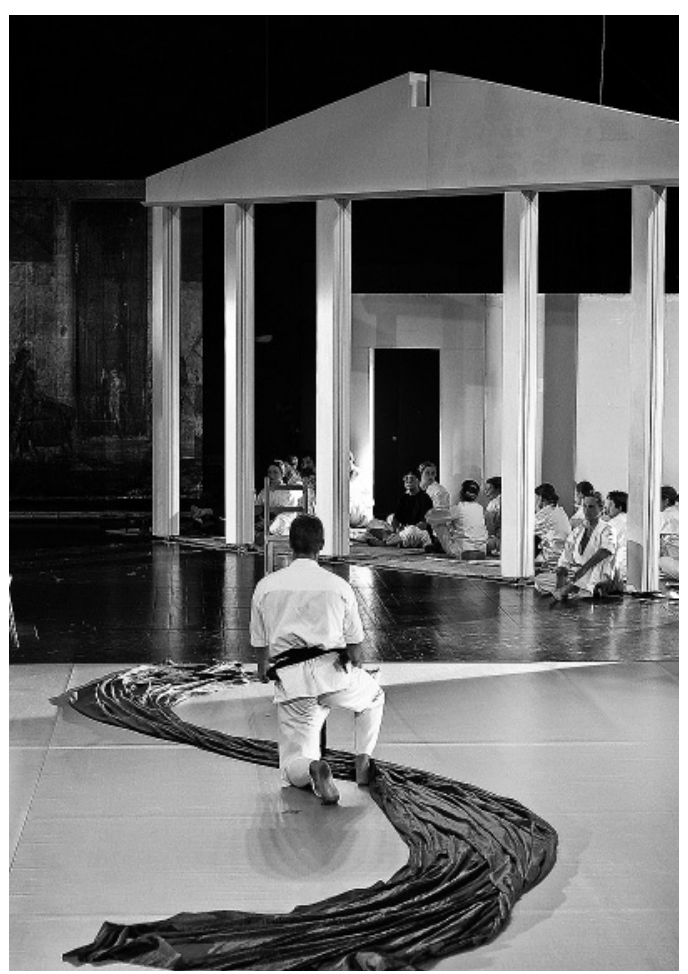

país não é tão grande que não tenhamos todos uma certa relação com Lisboa. Mas conhecer a cidade, o que são as suas populações, o que é que as aproxima ou afasta dos objectos estéticos que aqui podemos apresentar, o que é que falta aqui para aquilo que os criadores querem dizer o que é que o facto de essencialmente trabalharmos para uma percentagem ínfima da população significa, como é que se rompe com essa realidade protegida e burguesa em que os teatros em Portugal geralmente vivem, sem cairmos num populismo de indole comercial, nem num outro populismo que recorra a um multiculturalismo fácil, ou em situações do tipo infantilizar um segmento da população e chamar-Ihe comunidade, coisas desse tipo. Não quero dizer que não possa cair num destes precipícios, mas estou a tentar perceber como é que se rompem paredes, como é que o teatro transborda e traz pessoas para dentro, sem deixar de conferir atenção ao que são os projectos de criação e aquilo que se gera a partir daí.

AMS: 0 teu projecto apresenta, e estou a citar, "uma valoração máxima em todos os critérios de valoração enunciados". Os dados tal como são apresentados parecem referir um projecto denso e coerente. Propões "uma programação pluridisciplinar", que "embora dando prioridade à difusão, não descura a criação", apostando numa "relação muito clara com a comunidade urbana, e não só". Podes concretizar um pouco o que aqui se diz?

JLF: Isso que estás a ler são argumentos que o júri utilizou no relatório final do concurso, e correspondem àquilo que eram os objectivos que estavam no caderno de encargos da EGEAC [Empresa de Gestão de Equipamentos e

Animação Cultural], não é do meu projecto que eles extraem isso. Começando pelo fim: a pluridisciplinaridade é uma evidência, porque isto não é um teatro de criação não é um centro coreográfico, é um teatro municipal. De alguma maneira, a utopia seria tentar criar com públicos 


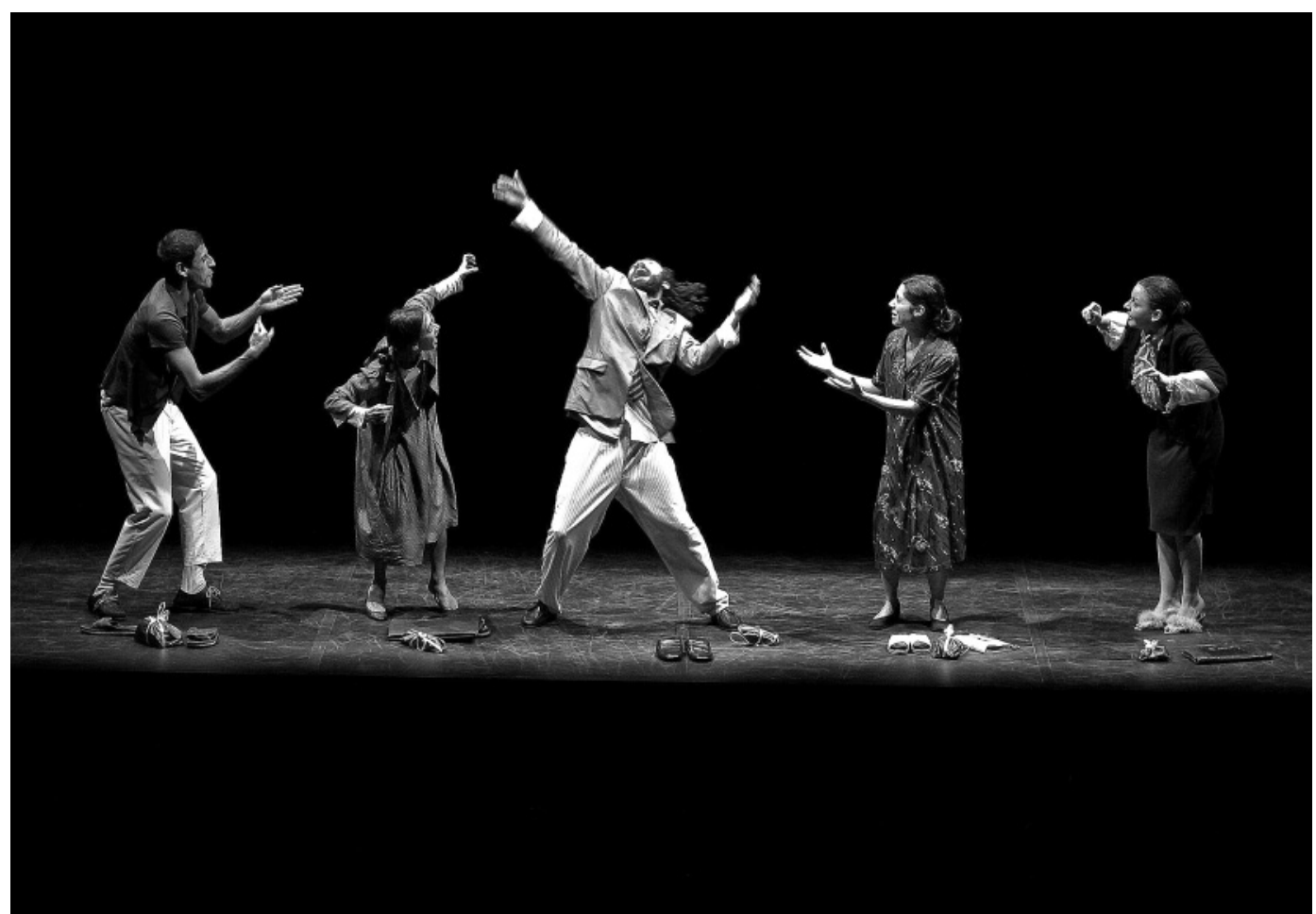

concretos mas o mais alargados possivel, uma espécie de relação total, que permitisse ao público, ao munícipe de Lisboa, ter essa experiência toda no São Luiz. Mas a segmentação decorrente da existência de espaços e instituições como a Gulbenkian, o S. Carlos, faz com que haja territórios em que não vale a pena sequer entrar. $E_{\text {, }}$ contudo, o desejo é esse: que uma pessoa que estabeleça uma relação com esta casa possa acompanhar a criação nas suas diversas linguagens, perceber o que são os caminhos contemporâneos de cruzamento dessas linguagens. Mas eu sempre fui mais atento ao exercicio das linguagens do que ao cruzamento dessas linguagens, acho que é importante haver territórios em que as linguagens também se possam continuar a desenvolver em si. A pluridisciplinaridade é uma necessidade aqui, neste teatro, e tem a ver não apenas com a pluralidade das linguagens artísticas como com a exploração de possibilidades da relação deste espaço com a cidade. É o caso, por exemplo, daquilo a que se chama a área do pensamento: a discussão, o debate, a audição em conferência de pessoas cuja visão do mundo pode mudar a nossa, as artes visuais, a literatura e os modos que ela tem de se dar, a leitura em conjunto, os debates sobre a obra e sobre o autor. Este não é, em primeiro lugar, um espaço de criação artística: é um espaço de relação entre a criação e a comunidade, como realidade abrangente, incluindo todas as pessoas que um dia aqui podem entrar. 0 projecto é mais um conjunto de interrogações do que afirmações, ou melhor, um conjunto de afirmações que tentam mostrar-se como questões a resolver para chegar a um fim. 0 que eu fiz não foi apresentar um projecto de programação para uma temporada, foi antes enunciar mais ou menos exaustivamente aquilo que seriam os objectivos estratégicos, aquilo que seriam as formas de relação para chegar a esses objectivos estratégicos, 0 modo como eu vejo o tecido artístico da cidade e do pais, sem ter a presunção de o conhecer todo, claro. 0 projecto que eu apresentei é um enunciado complexo disto: é um conjunto de princípios com os quais concordo plenamente, mas que não sei sempre como é que se transformam em realidades concretas. Um dos primeiros princípios, e pode não parecer ser um princípio importante para um teatro municipal, será o de tentar que a possibilidade de utilização da expressão artística entre dentro do corpo de cada cidadão, pondo-o a cantar, pondo-o a dançar. Não que isso substitua aquilo que é uma prática profissional e exigente das artes, mas porque isso pode tornar mais claro e transparente que, quando estamos a falar de cultura em geral, de domínio intelectual, de criação artística, não estamos a falar de nada que exista para elites ou para um nicho segregado da sociedade, mas estamos antes a falar de qualquer coisa que deveria ser uma linguagem comum, de qualquer coisa que nos diferencia e nos torna humanos. Quanto mais armas tivermos para o desenvolver e compreender, melhor. Acho que a capacidade para o exercício real da expressão artística altera os processos mentais de reflexão, de raciocínio. Há vários projectos de que posso falar, como, por exemplo, um projecto da Anne Teresa de Keersmaeker, da companhia Rosas, Dancing Kids, que ela própria anima em Bruxelas, um espaço para miúdos que não dançam, mas que vêm fazer um workshop de um dia, e aprender a usar o corpo com algumas regras, mas em liberdade. Pode parecer paradoxal, mas é libertar o uso do corpo aprendendo algumas regras básicas do uso do corpo. Depois isso já não passa propriamente por um projecto artístico em si próprio, porque eu não acredito que haja fórmulas feitas para alargar o território do destinatário, não é propriamente popularizando a programação no mau sentido que isso se consegue, mas criando mecanismos reais de comunicação para atingir públicos que eventualmente ou habitualmente não vêm cá. Esta é uma ambição desmesurada, numa sociedade contemporânea em que os centros estão vazios e gentrificados, as orlas estão massificadas e é cada vez 
A Short History of Crying de Sanja Mitrovic, Stand Up Tall Production

hetveem theater, Centre for Cultural Decontamination, Odisseia: Teatro do Mundo, 2011 (Sanja Mitrovic), fot. Laurent Liefoghe.

Policarpo Quaresma de Lima Barreto, enc. Antunes Filho,

Grupo de Teatro

Macunaima, Odisseia: Teatro do

Mundo, 2011,

fot. Emídio Luisi.
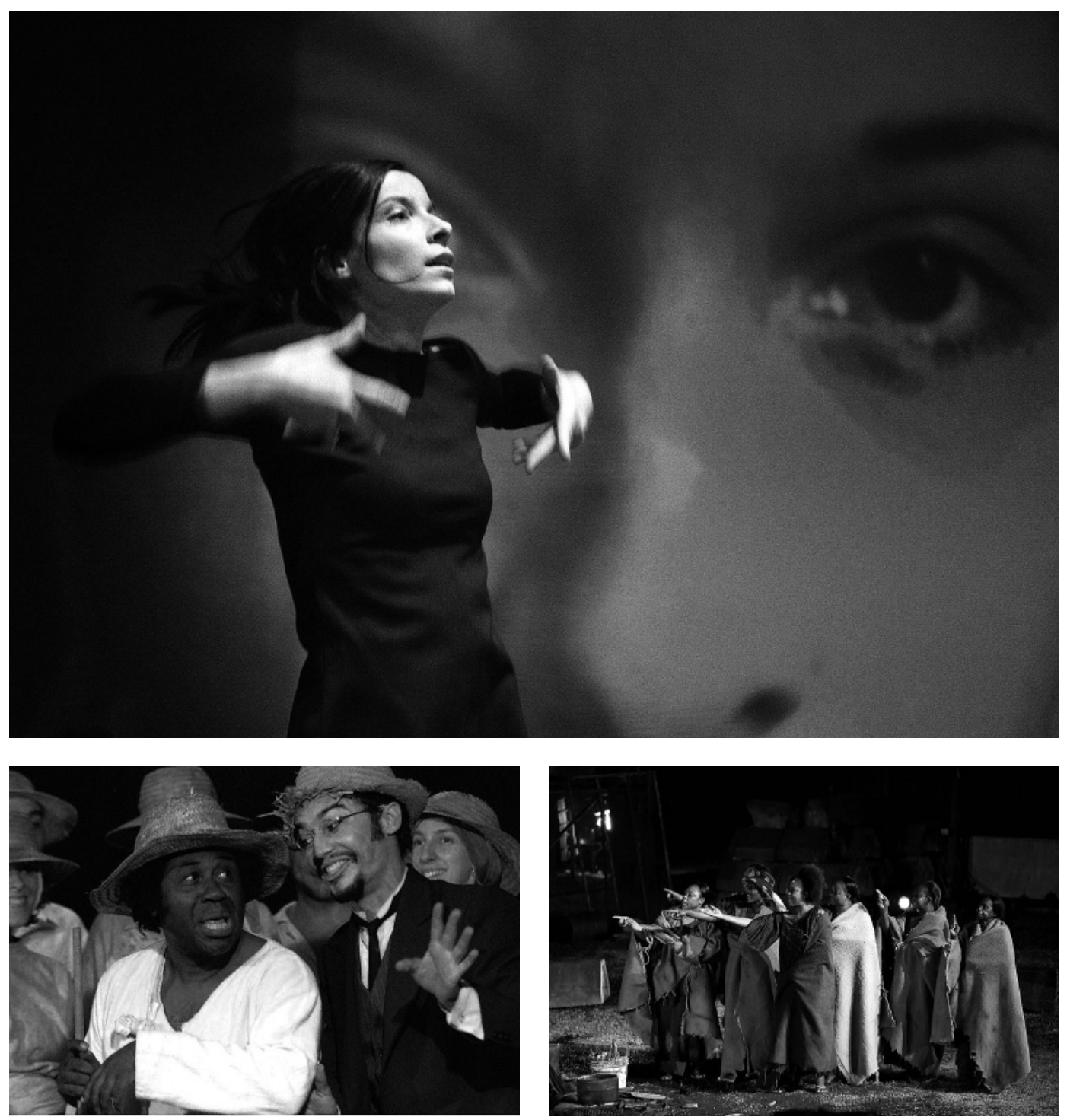

mais dificil viver numa cidade destas. Achar que as pessoas, que normalmente não vêm ao Chiado, vão passar a vir ao São Luiz é uma ambição enorme. Mas é tacteando este tipo de caminhos que se pode encontrar a relação com a cidade.

AMS: Voltamos à questão da rede...

JLF: Para terminar a relação com a cidade: a relação com a cidade passa pela relação com os artistas também, que não deixam de ser cidadãos. Uma espécie particular de cidadãos, mas tão cidadão como os outros, com uma actividade específica que tem aqui a sua fábrica. Mas isto para dizer que não acredito num programador ou director artístico de um espaço destes como uma espécie de designer da experiência estética da cidade, que de repente vai decidir o que é que o cidadão vai conhecer ou saber. A programação real faz-se a partir daquilo que são os desejos dos artistas, que podem ser confrontados com propostas, um diálogo ou comentário que pode influenciar o seu trabalho, mas o ponto de partida - e ponto de chegada - é o trabalho deles. A cidade é a cidade, Lisboa é a capital do pais, e há que saber ser capital. Há um raciocínio um bocadinho mecânico, que se vê muito nesta área, e que diz que o que se passa na capital é nacional, o que se passa noutros sítios é regional. Não concordo com este raciocínio, qualquer coisa que se passa em Freixo de Espada-à-Cinta pode ser nacional, regional, local ou inexistente, e Lisboa como capital tem de saber reconhecer aquilo que tem expressão nacional e dar-Ihe condições para alcançar essa dimensão nacional. 0 que se passa num sítio qualquer, se encontrar formas de relação com públicos alargados na capital, alcança uma expressão nacional diferente. E se Lisboa tem mais recursos e consegue captar, ou atrair, as forças criativas do país todo, isso também Ihe confere uma obrigação de devolução desse capital ao resto do país. E também não acredito no ensimesmamento: acho que a partilha de investimento é cada vez mais a única maneira de romper o confinamento a que os projectos estão cada vez mais votados. Quer dizer: é preferivel fazer um projecto em co-produção com outros teatros e permitir assim uma certa difusão, permiti que o projecto atinja uma certa escala, a fazer solos com todas as companhias e com todos os criadores, porque é a única coisa que se pode produzir sozinho. E se há coisa que aprendi no meu percurso, é o de ignorar aquilo a que se chamava fronteira. 0 país é um território para muita coisa, há muitas coisas que só existem aqui, mas o cosmopolitismo é exactamente saber trabalhar sobre e 

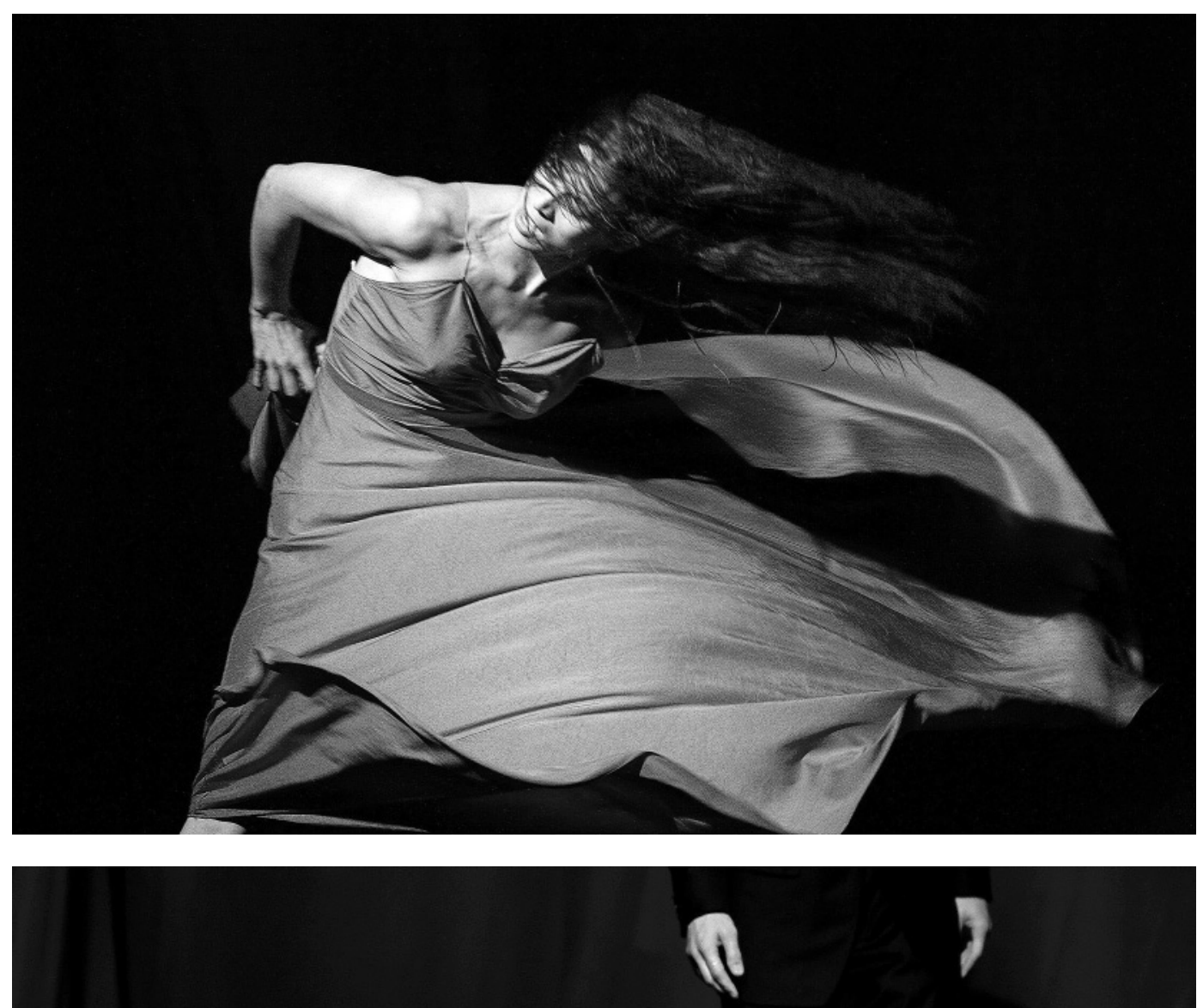

Sweet Mambo, de Pina Bausch, Tanztheater Wuppertal, Odisseia: Teatro do

Mundo, 2011, fot. Oliver Look.

com coisas que só existem aqui, mas com os outros, e de um modo aberto.

E acredito na Europa, apesar de parecer estranho e improvável, e acho a Europa uma aventura francamente excitante. E tal como relativamente ao país, a Europa funciona com a responsabilidade de todos, não apenas graças a terceiros, constrói-se com todos, com os cidadãos e com muitas formas de intervenção que estão para além de sistemas mecânicos de funcionamento, de consumo político normal. E os artistas e as práticas de criação artística situam-se sempre na vanguarda das mudanças que podem depois acontecer a nivel social mais profundo. Daí essa relação internacional e não a consideração de fronteiras para a realização de projectos.

JC: Um teatro nacional ou municipal abre as portas e quase só por isso tem público garantido. Achas que é verdade?

JLF: A resposta situa-se em dois planos. À partida, diria que tem obrigação disso. Por outro lado, que isso tem de ser visto em função da singularidade dos projectos. Isso tem de ser associado a uma ideia de risco e de espaço 

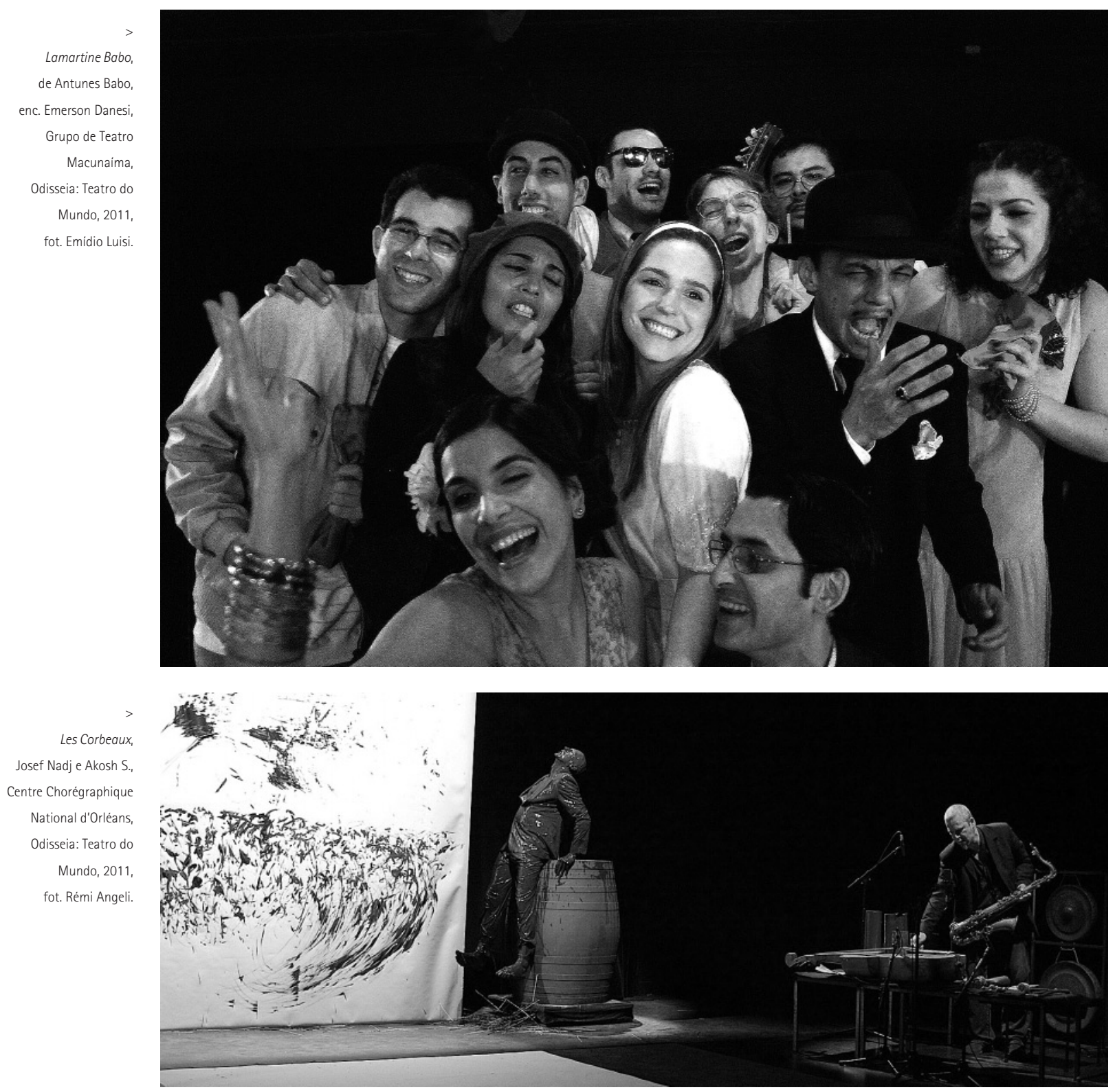

para fazer aquilo que à partida não tenha garantido esse sucesso. Se a ambição utópica do São Luiz for gerar uma relação forte de confiança e potencialmente total com públicos concretos, isso significa que, passado algum tempo de desenvolvimento do projecto, haja uma inércia de públicos, uma capacidade de confiança de públicos mais ou menos alargados para virem satisfazer a sua curiosidade perante projectos que à partida poderiam ser considerados minoritários, que isso contribua efectivamente para o enriquecimento da experiência dessas pessoas e que isso faça com que projectos de menos público, eventualmente, conheçam a experiência de um grande público. Mas tudo isto é tendencial e isso tem sido corroborado nesta experiência, que ainda é muito curta, pela experiência de popularidade aqui, nomeadamente em projectos relacionados com música, e pela reacção do público relativamente a projectos talvez mais obscuros, considerados à partida mais difíceis, que não tiveram a mesma procura. Acho que a vida do teatro se faz com as duas coisas. Quando digo que é essencial ter uma relação com a cidade, isso não exclui a consciência de que há domínios da criação que, por muitas razões, não chegam, não querem, ou não têm o desejo de chegar a um grande público, mas que são tão pertinentes como os outros, e que uns só podem existir porque os outros também existem. Há uma analogia fácil de fazer recorrendo a um argumento popularucho: por exemplo, Sarah Palin quando faz comentários sobre a verba exorbitante que se investia no campo da investigação referente à mosca do vinagre, não sabia que foi essa investigação que permitiu saber coisas essenciais sobre o genoma humano. Há que tentar perceber em que é que aquilo que, sendo minoritário, sendo pequeno, contribui para aquilo que é maioritário, ou maior. Este espaço do Jardim de Inverno tem caracteristicas particulares, é muito convivial, onde se podem fazer espectáculos, mas também outras coisas. Estamos a tentar ver, com a EGEAC, como fazer aqui um investimento para qualificar este espaço, com um sistema móvel, de modo a que receba também espectáculos, de pequena escala, para que seja um pequeno auditório, mas com exigências que neste momento não podem ser satisfeitas. 